\title{
Ultrasound biomicroscopy after palliative surgical procedures for bullous keratopathy: a descriptive comparative study
}

\author{
Biomicroscopia ultrassônica após procedimentos cirúrgicos paliativos na ceratopatia bolhosa: \\ estudo comparativo descritivo
}

Fabiana dos Santos Paris ${ }^{1}$, Eliana Domingues Gonçalves ${ }^{1}$, Maira Saad Ávila Morales ${ }^{1}$, Lillane Andrade Almeida Kanecadan ${ }^{1}$, Mauro Silveira de Queiroz Campos $^{1}$, José Álvaro Pereira Gomes ${ }^{1}$, Norma Allemann ${ }^{1}$, Elcio Hideo Sato ${ }^{1}$

\begin{abstract}
Purpose: To describe quantitative and qualitative features of eyes with advanced bullous keratopathy assessed using ultrasound biomicroscopy, before and after anterior stromal puncture (ASP) or amniotic membrane transplantation (AMT) procedures to relieve chronic pain.

Methods: The present descriptive comparative study included 40 eyes of 40 patients with chronic intermittent pain due to bullous keratopathy who were randomly assigned to one of the two treatments (AMT or ASP). Ultrasound biomicroscopy (Humphrey, UBM 840, 50 MHz transducer, immersion technique) was used, and a questionnaire about pain intensity was completed preoperatively and postoperatively at days 90 and 180, respectively. Exclusion criteria were age $<18$ years, presence of concurrent infection, ocular hypertension, and absence of pain. Results: In a 180-day follow-up, the AMT group exhibited mean central corneal thickness (CCT), 899.4 $\mu \mathrm{m}$ preoperatively and $1122.5 \mu \mathrm{m}$ postoperatively $(p<0.001)$; mean epithelial thickness (ET), $156.4 \mu \mathrm{m}$ preoperatively and $247.8 \mu \mathrm{m}$ postoperatively $(\mathrm{p}<0.001)$; and mean stromal thickness (ST), $742.9 \mu \mathrm{m}$ preoperatively and $826.3 \mu \mathrm{m}$ postoperatively $(\mathrm{p}=0.005)$. The ASP group exhibited mean CCT, $756.7 \mu \mathrm{m}$ preoperatively and $914.8 \mu \mathrm{m}$ postoperatively $(\mathrm{p}<0.001)$; mean $\mathrm{ET}, 102.1 \mu \mathrm{m}$ preoperatively and $245.2 \mu \mathrm{m}$ postoperatively $(\mathrm{p}<0.001)$; and mean ST, $654.6 \mu \mathrm{m}$ preoperatively and $681.5 \mu \mathrm{m}$ postoperatively $(\mathrm{p}<0.999)$. Correlations between CCT and pain intensity in the AMT group ( $p=0.209$ pre- and postoperatively) and the ASP group ( $p=0.157$ preoperatively and $p=0.426$ at the 180 -day follow-up) were not statistically significant. Epithelial and stromal edema, Descemet's membrane folds, epithelial bullae, and the presence of interface fluid were frequently observed qualitative features.
\end{abstract}

Conclusion: CCT increased over time in both groups. The magnitude of CCT did not correlate with pain intensity in the sample studied. The presence of interface fluid was a qualitative feature specifically found in some patients who underwent AMT.

Keywords: Corneal edema; Corneal endothelial cell loss; Corneal pachymetry; Cornea/ ultrasound; Amnion/transplantation; Biological dressings; Palliative care

\section{RESUMO}

Objetivo: Descrever as características quantitativas e qualitativas da biomicroscopia ultrassônica (UBM) em olhos com ceratopatia bolhosa avançada, antes e após os procedimentos de punção estromal anterior (ASP) ou transplante de membrana amniótica (AMT) para alívio de dor crônica.

Métodos: Estudo comparativo descritivo incluindo 40 olhos de 40 pacientes com dor crônica intermitente devido a ceratopatia bolhosa, randomizados em duas modalidades de tratamento (AMT e ASP). Biomicroscopia ultrassônica (Humphrey, UBM 840 , transdutor de $50 \mathrm{MHz}$, técnica de imersão) foi utilizada, e um questionário de avaliação da intensidade da dor foi aplicado no pré-operatório, e após 90 e 180 dias de pós-operatório. Critérios de exclusão foram: idade abaixo de 18 anos, presença de infecção, hipertensão ocular, e ausência de dor.

Resultados: No seguimento de 180 dias, o grupo Transplante de membrana amniótica

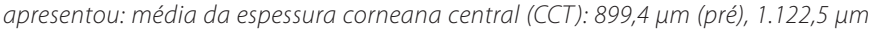

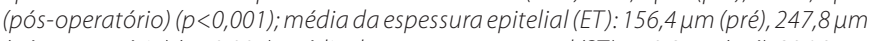
(pós-operatório) ( $p<0,001$ ); média da espessura estromal (ST): 742,9 $\mu \mathrm{m}$ (pré), 826,3 $\mu \mathrm{m}$ (pós-operatório) ( $p=0,005)$, e, grupo ASP apresentou: CCT média: $756.7 \mu \mathrm{m}$ (pré),

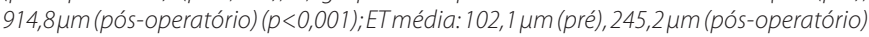
( $p<0,001)$; ST média: 654,6 4 m (pré), 681.5 um (pós-operatório) $(p<0,999)$. A correlação entre intensidade da dor e espessura corneana central no grupo AMT ( $p=0,209$ pré e pós-operatórios) e no grupo ASP ( $p=0,157$ pré-operatório e $p=0,426$ aos 180 dias de seguimento) não foi significativa. Edema epitelial e estromal, dobras na membrana de Descemet, bolhas epiteliais, e presença de fluido na interface foram características qualitativas frequentemente observadas.

Conclusão: A espessura corneana central aumentou ao longo do tempo em ambos os grupos. A magnitude da espessura corneana central não interfere na intensidade da dor na amostra estudada. Presença de fluido na interface foi uma característica qualitativa especificamente encontrada em alguns pacientes submetidos a transplante de membraa amniótica.

Descritores: Edema da córnea; Perda de células endoteliais da córnea; Paquimetria corneana; Córnea/ultrassonografia; Amnio/transplante; Curativos biológicos; Cuidados paliativos

\section{INTRODUCTION}

Bullous keratopathy (BK) is a disorder of the corneal endothelium in which the cell density is not sufficient to regulate corneal hydration and maintain corneal clarity ${ }^{(1)}$. Clinically, BK presents with stromal edema and epithelial blisters, leading to decreased visual acuity and pain ${ }^{(2,3)}$. The main causes of BK are related to advanced age; trauma; absolute glaucoma; primary corneal endotheliopathies, such as Fuchs'endothelial dystrophy; and endothelial cell loss following surgical interventions, such as cataract surgery with or without intraocular lens implantation (anterior or posterior chamber pseudophakic implants), vitreoretinal surgery (particularly when silicone oil is used),
Submitted for publication: August 12, 2014

Accepted for publication: September 29, 2014

Study was conducted at Federal University of São Paulo (UNIFESP), São Paulo, SP, Brazil.

Department of Ophthalmology and Visual Sciences, Federal University of São Paulo (UNIFESP), São Paulo, SP, Brazil.
Funding: This study was supported by Foundation for Support to Research of São Paulo State, (FAPESP) grant number 2001/07036-3.

Disclosure of potential conflicts of interest: None of the authors have any potential conflicts of interest to disclose.

Corresponding author: Fabiana dos Santos Paris. Av. Pedro de Toledo, 760/94 - Marília -SP - 17509-020 - Brazil - E-mail: fabiana.paris@hotmail.com

Approved by the following research ethics committee: Federal University of São Paulo (UNIFESP), São Paulo, SP, Brazil (0728/02).

Clinical trials registration: The study was registered at clinicaltrials.gov (Identifier: NCT 00659308). 
and penetrating keratoplasty (PK) following graft failure or immune rejection ${ }^{(1,3-7)}$.

Corneal graft is the definitive treatment for BK, restoring vision (when possible) and providing pain relief. Other treatments can be used for patients with no potential for vision restoration or while patients are waiting for a corneal graft. Such treatments include the use of topical $5 \% \mathrm{NaCl}$ hypertonic solution, non-steroidal anti-inflammatory agents, antiglaucomatous medications, therapeutic contact lenses, conjunctival flaps, electrocauterization, annular keratotomy, phototherapeutic keratectomy, anterior stromal puncture (ASP), and amniotic membrane transplantation (AMT) ${ }^{(3,8-12)}$.

In order to compare the effectiveness of ASP and AMT for the relief of pain in patients with advanced $\mathrm{BK}^{(3)}$, central corneal thickness (CCT) was considered to be an important variable, although it exceeded the upper limit for ultrasound pachymetry. Ultrasound biomicroscopy (UBM) is considered to be an alternative method for measuring CCT because it is an imaging method that provides cross-sections of the intact anterior segment of the eye at microscopic resolution. UBM has been used as an aid in diagnoses of ocular disease, as predicted by Pavlin et al. in 1991, when the method was first described ${ }^{(13-16)}$ and provides highly detailed images of the cornea, allowing the characterization of structural changes of the corneal layers.

In the present study, we assessed quantitative and qualitative features of eyes with advanced BK using UBM, and its association with pain intensity before and after patients underwent ASP or AMT.

\section{METHODS}

The present descriptive comparative study was conducted over 18 months and was part of a randomized prospective study com- paring ASP and AMT in the management of pain in patients with symptomatic BK. The inclusion criteria were chronic pain related to BK in patients on the waiting list for a corneal transplant or in patients whose affected eye had no or minimal visual potential and no indication for corneal transplant. Written consent was obtained from all enrolled patients. Exclusion criteria were age $<18$ years, presence of concurrent infection, increased eye pressure, and absence of pain.

A detailed history was obtained from each patient, including the administration of a questionnaire for assessing pain. Patients were asked to score the maximum intensity of pain experienced in the preceding one-month period on a scale of 1 to $10(1=$ minimal pain and $10=$ unbearable pain $)^{(3,8)}$. Clinical ophthalmologic examinations were conducted, including best corrected visual acuity, slit-lamp examination and photographic documentation with and without fluorescein staining, and Goldman tonometry ${ }^{(3)}$. Quantitative (CCT) and qualitative aspects of the cornea with BK were evaluated using UBM.

The same ophthalmologist (FSP) implemented randomization (using a computer-generated list of random numbers) as follows: 45 patients were considered, of whom 40 patients (40 eyes) were enrolled in the present study. Five patients were excluded: three of whom had previously undergone ASP, one had presented with herpes virus corneal infection, and one had raised intraocular pressure. At the outset, there were 20 patients in each group (AMT and ASP). After randomization, two patients in the ASP group were excluded from the analysis, as described in figure 1.

The causes of BK were endothelial lesion related to previous cataract surgery in 17 (85\%) patients in the AMT group, and in 14 (77.7\%) patients in the ASP group ( $p=0.102)$. Of the 17 patients enrolled in the AMT group, nine had additional surgical procedures: trabeculectomy

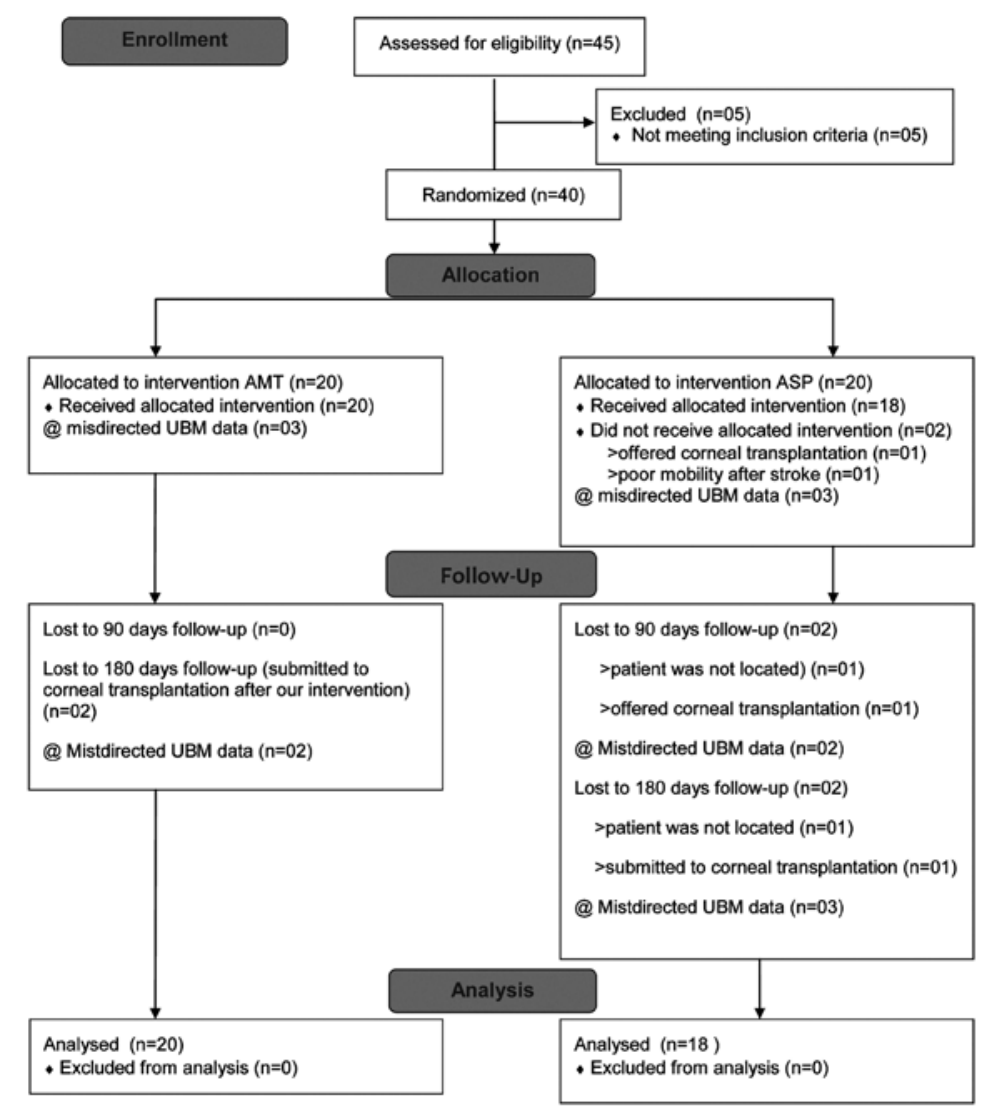

$\mathrm{AMT}=$ amniotic membrane transplantation; $\mathrm{ASP}=$ anterior stromal puncture; $\mathrm{UBM}=$ ultrasound biomicroscopy.

Figure 1. Study flow diagram. 
(three patients; one underwent reoperation), intraocular lens removal (three patients, two with associated vitrectomy), intraocular lens fixation (one patient), glaucoma valve implant associated with PK (one patient) and vitreoretinal surgery (one patient). Moreover, of the 14 patients in the ASP group, three underwent additional procedures: trabeculectomy (one patient underwent reoperation) and intraocular lens removal (two patients) $)^{(3,17)}$. Demographic characteristics and other clinical features are presented in table 1.

Both ASP and AMT procedures were performed by the same ophthalmologist (FSP) as previously described by Paris et al. ${ }^{(3)}$ Patients were followed up on days 1, 14, 30, 90, and 180 postoperatively.

UBM was performed preoperatively and at 90 and 180 days' follow-up. At the time of the study, the available equipment was a Humphrey UBM Model 840, 50-MHz transducer, and the examination was conducted under topical anesthesia with the aid of an immersion cup filled with $2 \%$ methylcellulose solution and $0.9 \%$ saline solution. To evaluate the central cornea, an axial scan was utilized, with $60 \mathrm{~dB}$ gain and $5.0 \mathrm{~mm}$ width $\times 5.0 \mathrm{~mm}$ depth in a vertical scan of the central cornea. If the patient was wearing a therapeutic contact lens, it was maintained during the UBM examination. Images were acquired and posteriorly analyzed, providing A-mode measurements of thickness (quantitative analysis) and B-mode features (reflectivity and anatomy; qualitative analysis). Parameters evaluated were the presence of epithelial bullae, epithelial thickening, stromal thickening, stromal reflectivity, and Descemet's membrane regularity. In the AMT group, the amniotic membrane thickness was included in the CCT measurement. In stored images for which posterior editing was not possible, a National Institute of Health ( $\mathrm{NIH}$ )-approved software for measurements (ImageJ64) that allows users to scale according to a given reference in the image and, subsequently, to measure the pa-

Table 1. Demographics and clinical features of patients with symptomatic bullous keratopathy divided in the two groups: anterior stromal puncture (ASP) and amniotic membrane transplantation (AMT)

\begin{tabular}{|c|c|c|c|}
\hline \multirow[b]{2}{*}{ Variable } & \multicolumn{2}{|c|}{ Group } & \multirow[b]{2}{*}{$p$} \\
\hline & AMT $(n=20)$ & $\operatorname{ASP}(n=18)$ & \\
\hline \multicolumn{4}{|l|}{ Age (years) } \\
\hline Mean (SD) & $64.1(15.1)$ & $66.2(13.9)$ & \multirow[t]{2}{*}{0.656} \\
\hline Range & $23-81$ & $42-85$ & \\
\hline \multicolumn{4}{|l|}{ Gender n (\%) } \\
\hline Male & $10(50 \%)$ & $4(22.2 \%)$ & \multirow[t]{2}{*}{0.076} \\
\hline Female & $10(50 \%)$ & $14(77.8 \%)$ & \\
\hline \multicolumn{4}{|l|}{ Affected eye } \\
\hline Right & $11(55.0 \%)$ & $9(50 \%)$ & \multirow[t]{2}{*}{0.758} \\
\hline Left & $9(45.0 \%)$ & $9(50 \%)$ & \\
\hline \multicolumn{4}{|l|}{ Disease duration (years) } \\
\hline Mean (SD) & $2.2(1.5)$ & $2.3(2.4)$ & \multirow{3}{*}{0.624} \\
\hline Median & 2.0 & 1.8 & \\
\hline Range & $0.17-5$ & $0.25-8$ & \\
\hline \multicolumn{4}{|l|}{ Etiology } \\
\hline Unknown & $0(0.0 \%)$ & $3(16.7 \%)$ & \multirow{4}{*}{0.102} \\
\hline Cataract surgery & $17(85.0 \%)$ & $14(77.7 \%)$ & \\
\hline Vitreorretinal surgery & $1(5.0 \%)$ & $0(0.0 \%)$ & \\
\hline Fuchs'endothelial dystrophy & $2(10.0 \%)$ & $1(5.6 \%)$ & \\
\hline
\end{tabular}

$\mathrm{AMT}=$ amniotic membrane transplantation; $\mathrm{ASP}=$ anterior stromal puncture; statistical tests used were student's t test or the Mann-Whitney test for independent samples, and $\mathrm{X}^{2}=$ test or Fisher's exact test. rameter of interest. ImageJ is a public-domain, Java-based imag-processing program developed at $\mathrm{NIH}$. The total thickness of tissue was considered in the measurements. If there was fluid in the interface, this fluid was not included in the measurement.

\section{Statistical analysis}

Data were presented as mean, standard deviation (SD), median, minimum and maximum values, or absolute and relative frequencies (\%), as appropriate. Patient characteristics and baseline variables were compared with respect to the quantitative variables using Student's $t$ test or the Mann-Whitney test for independent samples, and with respect to categorical variables using the $\chi^{2}$ test or Fisher's exact test. Spearman's correlation coefficient was used to measure the correlation of CCT with pain intensity preoperatively and at 90 and 180 days postoperatively ${ }^{(18)}$.

Nonparametric analysis of ordered categorical data in study designs with longitudinal observation, as described by Brunner and Langer, was performed to compare CCT, epithelial and stromal thickness (ST) distributions in both groups, and to compare preoperative and at 180-day follow-up within each group ${ }^{(19)}$. When differences were asssessed in ST analysis, $p$ values were corrected by Bonferroni inequalities ${ }^{(20)}$. Non-parametric analysis was required because assumptions for using a model of analysis of variance for repeated measures were not satisfied ${ }^{(20)} \cdot p<0.05(a=5 \%)$ was considered to be statistically significant.

\section{RESULTS}

In the 180-day follow-up, CCT and epithelial thickness (ET) increased $(p<0.001)$ in both groups. The results for the AMT group were CCT mean value, $899.4 \mu \mathrm{m}$ preoperatively and $1122.5 \mu \mathrm{m}$ postoperatively; ET mean value, $156.4 \mu \mathrm{m}$ preoperatively and $247.8 \mu \mathrm{m}$ postoperatively. The results for the ASP group were CCT mean value, $756.7 \mu \mathrm{m}$ preoperatively and $914.8 \mu \mathrm{m}$ postoperatively; ET mean value, $102.1 \mu \mathrm{m}$ preoperatively and $245.2 \mu \mathrm{m}$ postoperatively. ST measurements increased at the 180-day follow-up in the AMT group [ST mean value, $742.9 \mu \mathrm{m}$ preoperatively and $826.3 \mu \mathrm{m}$ postoperatively $(p=0.005)$ ], while the ASP group did not exhibit differences in ST following the intervention [ST mean value, $654.6 \mu \mathrm{m}$ preoperatively and $681.5 \mu \mathrm{m}$ postoperatively ( $p>0.999)]$. Details are presented in table 2 and figure 2 .

The correlations between CCT and pain intensity in the AMT group ( $p=0.209$ pre- and postoperatively) and the ASP group ( $p=0157$ preoperatively and 0.426 at 180 -day follow-up) were not significant, as seen in table 3.

The main features observed in UBM were: epithelial and stromal edema, 32 patients (100\%) preoperatively and 29 (100\%) in the 180-day follow-up in both the AMT and ASP groups; Descemet's membrane folds, four patients (23.5\%) preoperatively and four patients (25.0\%) at the 180-day follow-up in the AMT group, and three patients (20.0\%) preoperatively and two patients (15.4\%) at the 180-day follow-up in the ASP group; epithelial bullae, five patients (29.4\%) preoperatively and five patients (31.3\%) at the 180-day follow-up in the AMT group, and four patients (26.7\%) preoperatively and two patients [15.4\%] at the 180-day follow-up in the ASP group); and presence of fluid at the interface in three (17.6\%) patients in the AMT group. See figure 3.

\section{DISCUSSION}

Global trends show that after the advent of phacoemulsification, BK has become the leading indication of corneal and endothelial transplantation, particularly in developed countries ${ }^{(7,17,21-26)}$. Because patients with BK can experience severe pain, many clinical and surgical interventions intending to improve the quality of life for these patients can be attempted while they are waiting for a donor cornea or when visual potential is poor and transplant is contraindicated. 
Table 2. Descriptive statistical values for corneal central thickness, epithelial thickness and stromal thickness in AMT- and ASP-treated symptomatic eyes with bullous keratopathy preoperatively and at 90 and 180 days follow-up

\begin{tabular}{|c|c|c|c|c|c|c|c|c|}
\hline \multirow[t]{2}{*}{ Follow-up } & Group & $\mathbf{n}$ & Mean & SD & Minimum & Median & Maximum & IQ \\
\hline & \multicolumn{8}{|c|}{ Central corneal thickness $(\mathrm{m} \mu)$} \\
\hline \multirow[t]{3}{*}{ Preoperative } & AMT & 17 & 899.4 & 290.9 & 608 & 809.0 & 1603 & 330.0 \\
\hline & ASP & 15 & 756.7 & 294.6 & 463 & 718.0 & 1725 & 226.0 \\
\hline & Total & 32 & 832.5 & 296.8 & 463 & 778.0 & 1725 & 254.5 \\
\hline \multirow[t]{3}{*}{90 days } & AMT & 20 & 1075.3 & 314.6 & 723 & 950.5 & 1750 & 457.3 \\
\hline & ASP & 14 & 849.6 & 158.8 & 561 & 839.5 & 1100 & 208.3 \\
\hline & Total & 34 & 982.3 & 282.2 & 561 & 923.5 & 1750 & 292.8 \\
\hline \multirow[t]{4}{*}{180 days } & AMT & 16 & 1122.5 & 323.9 & 741 & 969.5 & 1720 & 583.5 \\
\hline & ASP & 13 & 914.8 & 274.9 & 573 & 862.0 & 1476 & 329.5 \\
\hline & Total & 29 & 1029.4 & 315.7 & 573 & 943.0 & 1720 & 443.5 \\
\hline & \multicolumn{8}{|c|}{ Epithelial thickness $(\mu \mathrm{m})$} \\
\hline \multirow[t]{3}{*}{ Preoperative } & AMT & 17 & 156.4 & 72.0 & 69 & 130.0 & 296 & 124.0 \\
\hline & ASP & 15 & 102.1 & 29.2 & 52 & 105.0 & 168 & 43.0 \\
\hline & Total & 32 & 130.9 & 61.8 & 52 & 114.5 & 296 & 43.3 \\
\hline \multirow[t]{3}{*}{90 days } & AMT & 20 & 195.0 & 108.5 & 52 & 179.5 & 440 & 129.8 \\
\hline & ASP & 14 & 212.9 & 120.3 & 84 & 185.5 & 568 & 73.5 \\
\hline & Total & 34 & 202.4 & 112.0 & 52 & 185.5 & 568 & 107.8 \\
\hline \multirow[t]{4}{*}{180 days } & AMT & 16 & 247.8 & 111.5 & 92 & 243.5 & 425 & 226.3 \\
\hline & ASP & 13 & 245.2 & 157.6 & 76 & 162.0 & 572 & 280.5 \\
\hline & Total & 29 & 246.6 & 131.6 & 76 & 243.0 & 572 & 245.5 \\
\hline & \multicolumn{8}{|c|}{ Stromal thickness ( $\mu \mathrm{m})$} \\
\hline \multirow[t]{3}{*}{ Preoperative } & AMT & 17 & 742.9 & 276.0 & 494 & 647.0 & 1470 & 363.5 \\
\hline & ASP & 15 & 654.6 & 297.9 & 364 & 600.0 & 1610 & 241.0 \\
\hline & Total & 32 & 701.5 & 285.3 & 364 & 619.5 & 1610 & 211.5 \\
\hline \multirow[t]{3}{*}{90 days } & AMT & 20 & 828.9 & 269.9 & 538 & 692.0 & 1418 & 410.3 \\
\hline & ASP & 14 & 636.6 & 119.3 & 370 & 630.5 & 880 & 128.0 \\
\hline & Total & 34 & 749.7 & 238.2 & 370 & 671.5 & 1418 & 157.3 \\
\hline \multirow[t]{3}{*}{180 days } & AMT & 16 & 826.3 & 306.0 & 507 & 703.0 & 1410 & 507.5 \\
\hline & ASP & 13 & 681.5 & 250.9 & 492 & 556.0 & 1343 & 257.0 \\
\hline & Total & 29 & 761.4 & 287.2 & 492 & 637.0 & 1410 & 318.0 \\
\hline
\end{tabular}

$\mathrm{SD}=$ standard deviation; $\mathrm{AMT}=$ amniotic membrane transplantation, $\mathrm{ASP}=$ anterior stromal puncture; $\mathrm{IQ}=$ interquartile interval. Nonparametric analysis of ordered categorical data in designs with longitudinal observations was performed.

Previous studies suggested that ASP and AMT are efficient treatments for pain relief in patients with advanced $B K^{(3,8-12)}$. Frequently, UBM is important for planning the surgical approach when there is potential for restoring vision in eyes with advanced BK and corneal opacity due to severe edema. Therefore, we believe that the increasing number of aphakic and pseudophakic BK associated with the use of palliative treatments, such as AMT and ASP, will be a common finding on UBM examination.

The definitive treatment to control edema with enlarged corneal thickness in BK is a penetrating or endothelial corneal graft. It is not surprising that, at the 180-day follow-up of the present study, CCT and ET showed significantly $(p<0.001)$ increased values in both the AMT and ASP groups because endothelial cell count was still reduced after the palliative treatments were proposed. In addition, the physical presence of the amniotic membrane contributes to the increase in CCT and ET values in the AMT group. Subepithelial fibrosis is described after AMT and ASP(3,8,27). This can constitute a barrier to fluid movement from the continuously hydrated stroma to the epithelium and can also decrease tissue evaporation, leading to stromal enlargement. This effect could be observed in the 180-day follow-up, when ST was significantly increased in the AMT group $(p=0.005)$.
Despite this, in the 180-day follow-up, ST did not significantly change in the ASP group $(p<0.999)$; thus, CCT increased at the expense of ET enlargement in the ASP group. Technically, an increase in ST could be a negative factor in a future corneal transplantation in the AMT group compared with the ASP group, considering that suturing a very thick receptor cornea might add technical difficulty due to the difference between donor and receptor corneal thickness.

The role of the amount of edema, here expressed by CCT, in pain intensity in patients with BK is uncertain. The presence of aberrant regeneration of stromal nerves may be a factor leading to pain in patients with BK, as demonstrated by Al-Aqaba in a histological and laser scanning confocal microscopy study. Al-Aqaba et al could not reach a conclusion regarding a correlation between corneal nerves changes and corneal thickness or the duration of corneal edema due to the limited number of $\operatorname{cases}^{(7)}$. Our sample constituted of advanced cases of BK, considering that the median time of beginning of symptoms was two years in the AMT group and 1.8 years in the ASP group ( $p=0.624$ ), which is consistent with the elevated values of CCT observed (mean, $832.5 \mu \mathrm{m}$; median, $778 \mu \mathrm{m}$ ), with a large variation (463-1725 $\mu \mathrm{m}$ ) considering the total number of studied eyes in the preoperative period $(n=32)$. The correlation between CCT and pain 
A

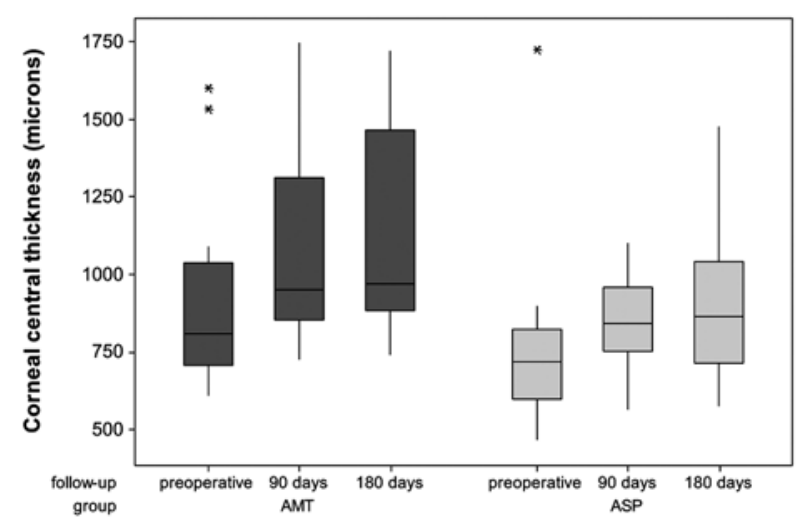

B

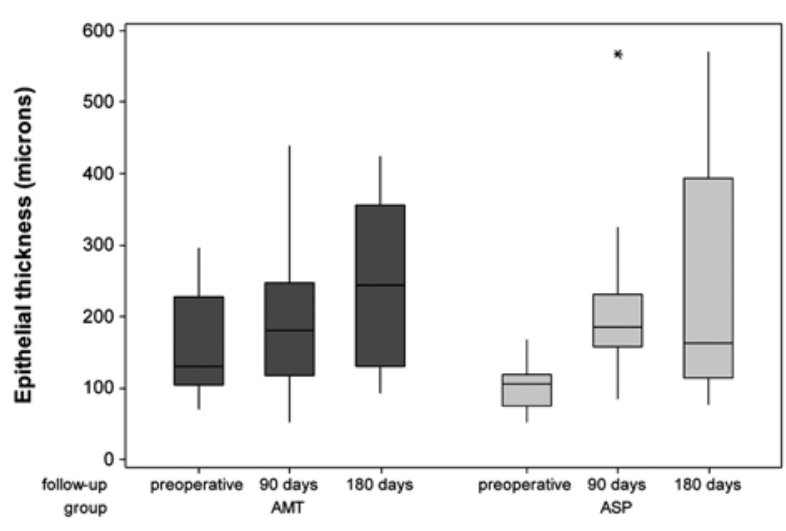

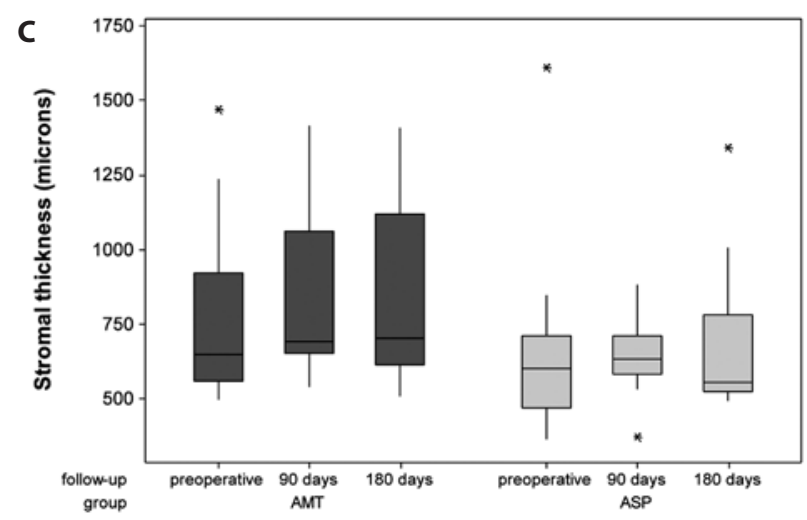

AMT = amniotic membrane transplantation; ASP= anterior stromal puncture. Nonparametric analysis of ordered categorical data in designs with longitudinal observations was performed.

Figure 2. Box-plots of corneal central thickness (A), epithelial thickness (B), and stromal thickness (C) in AMT and ASP-treated symptomatic bullous keratopathy eyes, preoperatively and at 90 and 180 days follow-up.

Table 3. Spearman's correlation coefficient of central corneal thickness (CCT) and pain intensity in preoperative and at 90 and 180 days postoperatively

\begin{tabular}{|c|c|c|c|c|c|c|}
\hline \multirow[b]{3}{*}{ Follow-up } & \multicolumn{6}{|c|}{ Group } \\
\hline & \multicolumn{3}{|c|}{ AMT } & \multicolumn{3}{|c|}{ ASP } \\
\hline & $\mathbf{r}$ & $\mathbf{p}$ & $\mathbf{n}$ & $\mathbf{r}$ & $\mathbf{p}$ & $\mathbf{n}$ \\
\hline Preoperative & 0.32 & 0.209 & 17 & -0.38 & 0.157 & 15 \\
\hline 90 days & -0.21 & 0.366 & 20 & 0.18 & 0.543 & 14 \\
\hline 180 days & 0.33 & 0.209 & 16 & 0.25 & 0.426 & 12 \\
\hline
\end{tabular}

AMT=amniotic membrane transplantation; $\mathrm{ASP}=$ anterior stromal puncture. The statistical test used was Spearman's correlation coefficient.

intensity was not significant in both groups preoperatively and at the 180-day follow-up (Table 3). New studies that correlate CCT with clinical and histological data should elucidate the influence of edema and corneal nerve changes in pain related to BK.

The main UBM characteristics in eyes with BK are epithelial and stromal edema, Descemet's membrane folds, and epithelial bullae. In clinical practice, these features are frequently observed when the endothelial barrier and the ionic pump functions are impaired, leading to epithelial fragility, neovascularization, and corneal opacification. Also, interface fluid [three eyes (17.6\%)] is a particular finding observed postoperatively in the AMT group. When the amnion-epithelial sheet is not fully attached to the corneal stroma after AMT, aqueous humor from the edematous stroma may lead to fluid accumulation in this interface. Said et al evaluated histological changes of receptor corneas of eyes with painful BK that underwent AMT before PK and observed that cells from the corneal stroma can migrate and proliferate on the amniotic stroma only through breaks in the Bowman's zone. In these sites of migration, the membrane was firmly attached to the corneal surface and, in regions with no breaks, hydration of the cornea and accumulation of fluid continued to occur, but without bullae formation because fluid did not appear to move beyond the transplanted re-epithelialized amnion. At slit-lamp examination, this was evidenced by the observation of a fluid cleft between the epithelialized amniotic membrane and the Bowman's zone ${ }^{(28)}$. Clinically, interface fluid does not appear to have an impact on pain intensity because none of these three patients reported pain in the 180-day follow-up.

We recognize that an anterior segment optical coherence tomography $(\mathrm{OCT})$ would visualize the digital sectioning of the cornea with high resolution, superior to UBM resolution. Both methods can provide the quantitative and qualitative information needed for the study; however, in contrast to OCT, UBM enables the measurement of corneal thickness $>1,000 \mu \mathrm{m}$, independently of the degree of opacity. At the preoperative measurement, we noted that some patients had CCT $>1,000 \mu \mathrm{m}$. Thus, UBM represents a potential alternative to measure corneal thickness and to evaluate details of densely opaque corneas in the entire sample. OCT would provide additional corneal pachymetric map with a non-contact technology. Although UBM requires immersion and could be a factor leading to an epithelial 

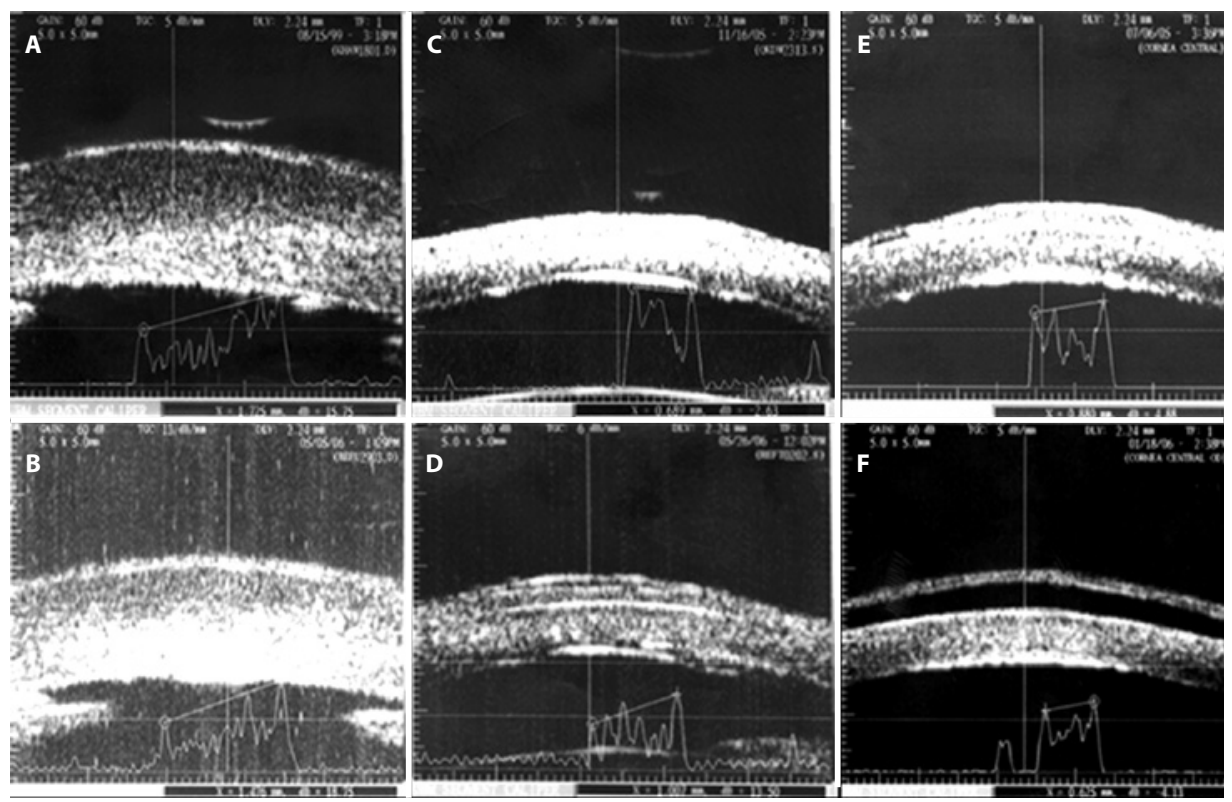

Figure 3. Ultrasound biomicroscopy in bullous keratopathy. Preoperative measures (3A, 3C, and 3E) demonstrating stromal hyper-reflectivity and thickening, epithelial thickening, and posterior surface irregularity (Descemet's membrane folds). Total corneal thickness was found to be 1,725 (3A), 689 (3C), and $880 \mu \mathrm{m}$ (3E). Examples of each group of treatment: 3B. Anterior stromal puncture with reduction in thickness $(1,476 \mu \mathrm{m}) ; 3 \mathrm{D}$. Amniotic membrane transplantation (membrane positioned at the corneal surface, interface detected); 3F. Amniotic membrane transplantation with a complication: presence of fluid in the interface between the membrane and corneal surface.

defect in fragile epithelium such as that observed in eyes with BK, therapeutic contact lenses after UBM examination was not routine.

\section{CONCLUSION}

At the 180-day follow up, CCT was increased $(p<0.001)$ in both groups (AMT and ASP). The magnitude of CCT did not correlate with pain intensity in the sample studied. Interface fluid was a qualitative feature specifically found in some patients submitted to AMT.

\section{REFERENCES}

1. Joyce NC. Cell cycle status in human corneal endothelium. Exp Eye Res. 2005;81(6): 629-38.

2. Pires RT, Tseng SC, Prabhasawat P, Puangsricharern V, Maskin SL, Kim JC, et al. Amniotic membrane transplantation for symptomatic bullous keratopathy. Arch Ophthalmol. 1999;117(10):1291-7.

3. Paris Fdos S, Goncalves ED, Campos MS, Sato EH, Dua HS, Gomes JA. Amniotic membrane transplantation versus anterior stromal puncture in bullous keratopathy: a comparative study. Br J Ophthalmol. 2013;97(8):980-4

4. Fischbarg J, Maurice DM. An update on corneal hydration control. Exp Eye Res. 2004 78(3):537-41.

5. Dighiero P, Guigou S, Mercie M, Briat B, Ellies P, Gicquel JJ. Penetrating keratoplasty combined with posterior Artisan iris-fixated intraocular lens implantation. Acta Ophthalmol. Scand. 2006:84(2):197-200.

6. Bourne WM, McLaren JW. Clinical responses of the corneal endothelium. Exp Eye Res. 2004;78(3):561-72.

7. Al-Aqaba M, Alomar T, Lowe J, Dua HS. Corneal nerve aberrations in bullous keratopathy. Am J Ophthalmol. 2011;151(5):840-9 e1.

8. Gomes JA, Haraguchi DK, Zambrano DU, Izquierdo Junior L, Cunha MC, de Freitas D. Anterior stromal puncture in the treatment of bullous keratopathy: six-month follow-up. Cornea. 2001;20(6):570-2

9. Tsai TC, Su CY, Lin CP. Anterior stromal puncture for bullous keratopathy. Ophthalmic Surg Lasers Imaging. 2003;34(5):371-4

10. Cormier G, Brunette I, Boisjoly HM, LeFrancois M, Shi ZH, Guertin MC. Anterior stromal punctures for bullous keratopathy. Arch Ophthalmol. 1996;114(6):654-8.

11. Thomann U, Niesen U, Schipper I. Successful phototherapeutic keratectomy for recurrent erosions in bullous keratopathy. J Refract Surg. 1996;12(2):S290-2.
12. Koenig SB. Annular keratotomy for the treatment of painful bullous keratopathy. Am J Ophthalmol. 1996;121(1):93-4.

13. Pavlin CJ, Harasiewicz K, Sherar MD, Foster FS. Clinical use of ultrasound biomicroscopy. Ophthalmology. 1991:98(3):287-95.

14. Madhavan C, Basti S, Naduvilath TJ, Sangwan VS. Use of ultrasound biomicroscopic evaluation in preoperative planning of penetrating keratoplasty. Cornea. 2000;19(1):17-21.

15. Avitabile T, Russo V, Ghirlanda R, Castiglione F, Marino A, Reibaldi A. Corneal oedemas: diagnosis and surgical planning with ultrasound biomicroscopy. Ophthalmologica. 1998;212 Suppl 1:13-6.

16. Allemann N, Chamon W, Silverman RH, Azar DT, Reinstein DZ, Stark WJ, et al. High-frequency ultrasound quantitative analyses of corneal scarring following excimer laser keratectomy. Arch Ophthalmol. 1993;111(7):968-73.

17. Paris Fdos S, Goncalves ED, Barros Jde N, Campos MS, Sato EH, Gomes JA. Impression cytology findings in bullous keratopathy. Br J Ophthalmol. 2010;94(6):773-6.

18. Johnson RA, Wichern DW. Applied Multivariate Statistical Analysis. $6^{\text {th }}$ ed. New Jersey; 2007.

19. Brunner E, Langer F. Nonparametric analysis of ordered categorical data in designs with longitudinal observations and small sample sizes. Biom J. 2000;42(6):663-75

20. Fisher LD, van Belle G. Biostatistics. New York: John Wiley \& Sons; 1993.

21. Ghosheh FR, Cremona FA, Rapuano CJ, Cohen EJ, Ayres BD, Hammersmith KM, et al. Trends in penetrating keratoplasty in the United States 1980-2005. Int Ophthalmol. 2008;28(3):147-53.

22. Tan DT, Janardhanan $\mathrm{P}$, Zhou H, Chan YH, Htoon HM, Ang LP, et al. Penetrating keratoplasty in Asian eyes: the Singapore Corneal Transplant Study. Ophthalmology. 2008;115(6):975-82 e1.

23. Goncalves ED, Campos M, Paris F, Gomes JA, Farias CC. [Bullous keratopathy: etiopathogenesis and treatment]. Arq Bras Oftalmol. 2008;71 (6 Suppl):61-4. Portuguese.

24. Al-Yousuf N, Mavrikakis I, Mavrikakis E, Daya SM. Penetrating keratoplasty: indications over a 10 year period. Br J Ophthalmol. 2004;88(8):998-1001.

25. Sano FT, Dantas PE, Silvino WR, Sanchez JZ, Sano RY, Adams F, et al. [Trends in the indications for penetrating keratoplasty]. Arq Bras Oftalmol. 2008;71(3):400-4. Portuguese.

26. Fabris C, Corrêa ZMS, Marcon AS, Castro TN, Marcon ÍM, Pawlowski C. Estudo retrospectivo dos transplantes penetrantes de córnea da Santa Casa de Porto Alegre. Arq Bras Oftalmol. 2001;64(5):449-53.

27. Sridhar MS, Vemuganti GK, Bansal AK, Rao GN. Impression cytology-proven corneal stem cell deficiency in patients after surgeries involving the limbus. Cornea. 2001;20(2): $145-8$

28. Said DG, Nubile M, Alomar T, Hopkinson A, Gray T, Lowe J, et al. Histologic features of transplanted amniotic membrane: implications for corneal wound healing. Ophthalmology. 2009;116(7):1287-95. 